\section{Genes and Linkage Groups in Genetics.}

I HAVE no intention of criticising in detail the elementary lecture on Mendelism which Prof. Huxley gives in NATURE of January 30, p. I54, as a supposed reply to my remarks in the issue of December 26 , 1925. Our minds are so differently constituted that what he regards as facts I consider to be unproved assumptions, and what he calls proof I consider to be begging the question. Nothing of what he says is new ; indeed much of it, it has been my painful duty to present to my students year after year whilst never concealing from them my utter scepticism as to the assumptions involved.

Prof. Huxley's statistics leave me entirely unmoved. Statistics in biology are a very dangerous weapon ; their value entirely depends on the validity and definable character of the unit which is counted. It is because I do not regard Morgan's units as having any validity whatever that I consider his deductions as valueless. These units are avowedly assumed in order to make his observations fit a preconceived theory; if the fit is not exact, then further units will be assumed in order to make the fit better, and this procedure he calls proof.

I should like, however, a brief space to set forth to readers of NATURE the reasons why, in company with some of my most distinguished colleagues, I regard the whole of this "factorial analysis" as both formal and futile.

In the first place, the supposed " genes " or " unit factors," even if we concede their existence, throw no light whatever on the course of evolution or on the past history of existing species. This is the opinion of those whose opinions are most entitled to respect in the realms of systematic zoology, of palæontology, and of embryology, which are the three great sources of our knowledge of evolution. What is the use of telling us that the constitution of an animal is to be represented by the factors $a, b, c$, $d, e, f$ and $g$, if it was not formerly represented by $a, b, c, d, e$ and $f$, and has become what it is by the addition of " $g$ "?-Yet when we examine in detail what the "factors" in Drosophila actually are, any competent entomologist would laugh to scorn the idea that they represent elements in the evolution of an actual insect. Secondly, what Morgan has proved in the case of Drosophila and what has been shown to occur in every case where plants are cultivated or animals bred in confinement in large numbers, is that sharp deviations from the type occur and that these aberrant individuals when crossed with the type exhibit Mendelian segregation in their inheritance. So universally is this the case that geneticists like Baur have been driven to assume that there must be "idiokinetic factors" in the environment to account for these mutations.

Now if the true object of science is rerum causas scire, once this fact has been well established, the next step should be to ascertain how the distinctive features of these mutations are acquired in the course of individual development and whether apparently unrelated mutations might not be due to varying intensities of the same disturbance of embryological processes. As I pointed out in the review which originally excited Prof. Huxley's criticism, we can show in the case of Vertebrata that "mutations" as apparently diverse in nature as mental defect and supernumerary fingers can be explained as due to varying degrees of abnormal amniotic pressure. Yet we look in vain in the work of the Morgan school for any trace of analysis of this sort.

Thirdly, when the course of individual development has been ascertained, the next step should be to try to find the environmental influences which have produced the disturbances of development. It is because Tornier has done this and has brought a great mass of direct and indirect evidence in support of his views that I regard his work as equal in value to that of all the other geneticists put together. Not only has he shown how mutations arise, but he has also thrown light on the still more interesting question of why these mutants when exposed to natural conditions tend to revert to type. This valuable work is of course only in its initial stages: like other pieces of important work, its course was interrupted by the War and has not been since resumed, but it is only along lines such as these and not by the assumption of imaginary factors that a ture explanation of the origin of mutations and of the physiological nature of Mendelian inheritance will ever be attained.

E. W. MAcBride.

\section{Greenland or Polar Front.}

To Mr. L. C. W. Bonacina's communication entitled "Greenland or Polar Front," which appeared in NATURE of November 2 I, p. 748 , I should like to make a brief reply. I must again insist upon the contrast which exists between the two polar regions of the earth, ${ }^{1}$ and repeat that, despite much misconception, the Arctic basin is neither cold nor dry relative to Greenland or, during the cold season, even to Siberia and British America. Nansen's observations made during the drift of the Fram show that 66.5 days in the year were foggy. Mr. Bonacina's statement that fogs did not occur during the winter, does not refer to the long cold polar season, but to the short period of December to February inclusive. Fogs occurred in every other month, and one day in every four was foggy for this period. During Capt. Amundsen's flight toward the Pole, fogs were so thick that little could be seen for much of the way, and near $89^{\circ} \mathrm{N}$. fogs were a serious handicap in taking off after the forced landing.

Mr. Bonacina urges in support of a supposed cold high-pressure "polar front" a pressure difference between the Arctic basin and the Icelandic low, but it is significant that within this very sector of the Arctic basin the dominant wind component along the meridian is not from the north, but from the south. Mohn's tables based upon Nansen's observations on the Fram for the year I895 (when the vessel zigzagged throughout along the $85^{\text {th }}$ parallel of latitude within the European sector) showed that for the entire year 59.4 per cent. of the wind force had a southerly component and only $40 \cdot 6$ per cent. a northerly. Reckoned for the periods November to April and May to October separately, the corresponding figures are for the southerly component 58.1 per cent. and 60.5 per cent. respectively. For the short winter season (December to February) when fogs were not observed and when, according to Mr. Bonacina, it might be supposed that cold air would move out southward from the Arctic basin, no less than 63.2 per cent. of the wind component reckoned along the meridian was from the south. ${ }^{2}$ As pointed out in my earlier communication to NATURE, the most striking fact which emerges from all the Fram observations is their monotony of character with but slight seasonal changes-these are the well-known characteristics of an expanse of sea.

The course of the Fram as it drifted in the ice supplies an even more striking proof that the dominant

1 William Herbert Hobbs, "L'asymétrie de la circulation atmosphérique," Comptes rendus de l'Acad. des Sciences, t. I8 I, I7 août 1925, pp. 289-290.

2 H. Mohn, "The Norwegian North Polar Expedition $1893^{-1} 896$, Scientific Results," London, vol. 6, I905, p. 315. 